Рощик I. А. [1; ORCID ID: 0000-0002-3155-2727], к.е.н., доцент,

Овсіюк М. В. [1; 0RCID ID: 0000-0001-6287-3876] здобувач вищої освіти другого (магістерського) рівня

${ }^{1}$ Національний університет водного господарства та природокористування, м. Рівне

\title{
ПРЕМІЮВАННЯ МЕДИЧНИХ ПРАЦІВНИКІВ У ЦЕНТРАХ НАДАННЯ ПЕРВИННОЇ МЕДИЧНОЇ ДОПОМОГИ
}

На основі аналізу колективних договорів, чинних у центрах надання первинної медичної допомоги, встановлено основні характеристики системи преміювання медичних працівників. Обґрунтовано актуальність ïх трансформування шляхом перекваліфікування премії за укладені декларації лікарів та медичних сестер, що 3 ними працюють, у підвищення посадового окладу та імплементація показників якості наданої первинної медичної допомоги в системи преміювання. Запропоновано застосовувати технологію «ключових показників ефективності», перелік та вага яких визначаються шляхом опитування медичних працівників центрів первинної медичної допомоги i узгоджуються із стратегічними цілями розвитку медицини первинної ланки. Наведено математичну модель розподілу премій між лікарями, впровадження якої дасть змогу реалізувати стратегію розвитку системи первинної медичної допомоги в напрямку покращення її якості.

Ключові слова: медичні працівники; якість первинної медичної допомоги; стимулювання персоналу; преміювання персоналу; ключові показники ефективності.

Постановка проблеми. Реформування медицини в частині урізноманітнення переліку організаційно-правових форм закладів охорони здоров'я неприватної форми власності зумовило розширення прав їх керівників більш комплексно управляти персоналом, зокрема змінюючи систему стимулювання медичних працівників. 3 іншого боку, в медицині відбулися зміни також в частині фінансування, зокрема заклади охорони здоров'я, що надають первинну медичну допомогу, стали фінансуватись не постатейно, а за принципом «гроші йдуть за пацієнтом». В результаті у більшості медичних закладів первинної ланки з'явився новий напрямок преміювання медичного персоналу - за кількість пацієнтів, яких вдалося залучити лікарю, оскільки внаслідок цього заклад отримує додаткові фінансові надходження. Разом з тим, поза увагою залишаються якісні показники роботи медичного персоналу, а отже, 
й резерви підвищення якості первинної медичної допомоги, що $є$ пріоритетним напрямом реформування медицини, закладеним у відповідній Національній стратегії [1] та інших програмних документах [2].

\section{Аналіз останніх досліджень}

Кадрова політика у сфері охорони здоров'я розкривається у публікаціях українських вчених 3 державного управління: Короленко В. В. [3], Авраменко Т.П. [4], Гуцалюк О.М. [5], Білинська М. М. [6]. Питання управління персоналом закладів охорони здоров'я висвітлюються у співавторстві 3 Коломойцем А. В. [7], КравчукІ.І. [8]. Цінними $€$ консультаційні матеріали з управління персоналом у медичних закладах $[9 ; 10 ; 11]$.

Разом з тим, питання стимулювання та преміювання медичних працівників розкриті недостатньо, оскільки актуальними є плинність медичних працівників та високий рівень захворюваності населення України.

Мета і завдання дослідження - обґрунтування теоретикометодичних засад трансформування механізму преміювання медичних працівників центрів надання первинної медичної допомоги.

\section{Виклад основного матеріалу}

Станом на кінець 2020 року в Україні налічується понад 1719 надавачів первинної медичної допомоги, які уклали договір із Національною службою здоров'я [12]. Більшість 3 них (1110 надавачів або 65\%) мають статус комунального некомерційного підприємства (КНП), керівник якого може самостійно визначати напрями використання отриманих підприємством доходів (з бюджетних та інших незаборонених законом джерел), враховуючи зафіксовані в колективному договорі положення про виробничі, трудові і соціально-економічні відносини.

Персоналом основної діяльності цих КНП є понад 22 тисячі [12] медичних працівників, які уклали декларації з пацієнтами - сімейних лікарів, терапевтів, педіатрів. Працівники цих категорій становлять понад 12\% [13, С. 129] усіх лікарів України та понад 2,3\% [14, С. 52] зайнятих в охороні здоров'я. При цьому в команді з кожним лікарем, як правило, працює 1-2 особи із числа молодшого медичного персоналу. Тому стимулювати осіб такої чисельної категорії зайнятих в охороні здоров'я покращувати кількість та якість своєї праці $\epsilon$ актуальним питанням сьогодення.

В результаті аналізу 20 інтернет-доступних колективних договорів між адміністраціями Центрів надання первинної медичної 
допомоги (ПМД) та їх трудовими колективами, що містять положення про оплату праці та преміювання, встановлено такі основні характеристики систем преміювання працівників цих категорій в Україні (табл. 1):

- найпоширенішими основними показниками преміювання лікарів та медичних сестер, які укладають декларації з пацієнтами, $\epsilon$ дохід від укладених декларацій та премія лікаря, який працює в команді, відповідно;

- поряд з основними показниками преміювання у більшості КНП застосовується багато додаткових: відсутність обґрунтованих скарг на рівень якості лікування та культури обслуговування; виконання стандартів діагностики, обстеження та лікування; поліпшення показників роботи;

Таблиця 1

Показники преміювання (депреміювання) медичних працівників центрів ПМД, які укладають декларації з пацієнтами

\begin{tabular}{|c|c|c|c|}
\hline № & $\begin{array}{c}\text { Показники преміювання } \\
\text { (депреміювання) }\end{array}$ & $\begin{array}{c}\text { Лікарі, які } \\
\text { укладають } \\
\text { декларації з } \\
\text { пацієнтами }\end{array}$ & $\begin{array}{c}\text { Фахівці з базовою і } \\
\text { неповною вищою } \\
\text { медичною освітою } \\
\text { (медичні сестри), що } \\
\text { працюють з лікарями, } \\
\text { які укладають } \\
\text { декларації } 3 \\
\text { пацієнтами } \\
\end{array}$ \\
\hline 1. & $\begin{array}{l}\text { Дохід від укладених } \\
\text { декларацій з пацієнтами }\end{array}$ & $\begin{array}{r}1,2,3,5,6,7 \\
9,10,12,13 \\
14,19,20^{*} \\
\end{array}$ & $\begin{array}{c}1,2,3,5,6,9,10,12 \\
13,14,19\end{array}$ \\
\hline 2. & $\begin{array}{l}\text { Норма укладання } \\
\text { декларацій }\end{array}$ & $15,(13),(14)$ & - \\
\hline 3. & $\begin{array}{l}\text { Позитивний результат } \\
\text { тестування на ВІЛ- } \\
\text { інфекцію }\end{array}$ & 1 & 1 \\
\hline 4. & $\begin{array}{l}\text { Частка пацієнтів } 3 \\
\text { позитивним результатом } \\
\text { тестування на туберкульоз }\end{array}$ & $1,8,(14)$ & 1 \\
\hline 5. & $\begin{array}{l}\text { Частка дітей до } 6 \text { міс. на } \\
\text { грудному вигодовуванні }\end{array}$ & 1 & 1 \\
\hline 6. & $\begin{array}{l}\text { Кількість публічних } \\
\text { заходів для популяризації } \\
\text { здорового способу життя }\end{array}$ & 13,14 & 13,14 \\
\hline 7. & $\begin{array}{l}\text { Кількість групових занять } \\
\text { для пацієнтів }\end{array}$ & - & 13,14 \\
\hline
\end{tabular}


продовження табл. 1

\begin{tabular}{|c|c|c|c|}
\hline 8. & $\begin{array}{l}\text { Частка імунізованого } \\
\text { населення }\end{array}$ & $8,(1)$ & - \\
\hline 9. & $\begin{array}{l}\text { Кількість } \\
\text { онкозахворювань у } \\
\text { занедбаній стадії з вини } \\
\text { лікаря }\end{array}$ & (1), (13), (14) & - \\
\hline 10. & $\begin{array}{l}\text { Кількість обгрунтованих } \\
\text { скарг }\end{array}$ & (1) & - \\
\hline 11. & $\begin{array}{l}\text { Порушення термінів } \\
\text { виконання доручень і } \\
\text { завдань }\end{array}$ & (14) & - \\
\hline 12. & $\begin{array}{l}\text { Порушення трудової } \\
\text { дисципліни }\end{array}$ & (11), (12) & - \\
\hline 13. & $\begin{array}{l}\text { Інші показники, технологія } \\
\text { вимірювання яких не } \\
\text { уточнюється }\end{array}$ & $\begin{array}{c}1,2,3,4,5 \\
6,8,10,12 \\
13,15,16 \\
17,18 \\
\end{array}$ & $\begin{array}{r}1,2,3,4,5,6,8,10 \\
12,13,15,16,17,18\end{array}$ \\
\hline
\end{tabular}

Джерело. Складено авторами за [15-34].

Примітка. Нумерація КНП та джерела використаної інформації: 1 - КНП «Центр ПМСД № 3 Дарницького району м. Києва [15]; 2 - КНП «Центр ПМСД № 1» Святошинського району м. Києва [16]; 3 - КНП «Тульчинський центр ПМСД» Тульчинської міської ради (Вінницька обл.) [17]; 4 - КП «Козятинський міський центр первинної медико-санітарної допомоги Козятинської міської ради» (Вінницька обл.) [18]; 5 - КНП «Центр ПМСД Покровської міської ради Дніпропетровської області» [19]; 6 - КНП «Центр ПМСД Мар"їнської районної ради» [20]; 7 - КНП Маріупольської міської ради «Центр ПМСД № 5 м. Маріуполя» (Донецька обл.) [21]; 8 - КНП «Центр ПМСД Полянської сільської ради Свалявського району Закарпатської області» [22]; 9 - КНП« Центр ПМСД № 2» м. Запоріжжя [23]; 10 - КНП Коломийської міської ради «Коломийський міський центр ПМСД» (Івано-Франківська обл.) [24]; 11 - КНП Бородянської районної ради «Бородянський центр ПМСД» (Київська обл.) [25]; 12 - КНП «Чорнухинський центр первинної медико-санітарної допомоги» Чорнухинської районної ради (Полтавська обл.) [26]; 13 - КНП «Центр ПМСД «Ювілейний» Рівненської міської ради [27]; 14 - КНП «Центр ПМСД «Північний» Рівненської міської ради [28]; 15 - КНП «Березнівський районний центр ПМД» Березнівської районної ради (Рівненська обл.) [29]; 16 - КНП «Володимирецький РЦ ПМСД» (Рівненська обл.) [30]; 17 - КНП «Краснопільський районний центр ПМСД» Краснопільської районної ради (Сумська обл.) [31]; 18 - КНП «Нижньосірогозький центр первинної медикосанітарної допомоги» (Херсонська обл.) [32]; 19 - КНП« Центр ПМСД Білозерського району» (Херсонська обл.) [33]; 20 - КНП «Центр ПМСД» Смілянської міської ради (Черкаська обл.) [34]

впровадження нових методів лікування; відсутність порушень у діяльності підрозділу; за виконання особливо важливої роботи; 3 метою заохочення працівника до високопродуктивної та 
високоякісної роботи; з нагоди ювілейних дат та на честь святкових дат тощо;

- дуже рідко медичних працівників преміюють (депреміюють) за виконання показників, які в нормативно-законодавчих документах в охороні здоров'я відносяться до індикаторів якості ПМД: позитивний результат тестування на ВІЛ-інфекцію; кількість онкозахворювань у занедбаній стадії; кількість випадків деструктивної форми туберкульозу; рівень грудного вигодовування; рівень вакцинопрофілактики тощо.

Розрахунок премії лікарів за отримання доходів від укладених декларацій у більшості українських Центрів ПМД відбувається шляхом множення суми відповідного доходу на коефіцієнт преміювання (від 6 до 20\%), а медичних сестер - шляхом множення премії лікаря на коефіцієнт преміювання (30-70\%). Умови нарахування премій цього виду не є однорідними: в одних Центрах премії призначаються тільки за певного рівня виконання норми укладання декларацій, в інших - немає такої умови, в одних Центрах встановлюються різні коефіцієнти преміювання у разі невиконання або перевиконання норми укладання декларацій, в інших коефіцієнти преміювання не залежать від рівня виконання цієї норми. Інколи зустрічаються випадки, коли премія розраховується у відсотковому відношенні, яке дорівнює коефіцієнту виконанню норми укладання декларацій, до посадового окладу. При цьому медичні сестри премію не отримують. В деяких Центрах премія зменшується, якщо норма укладання декларацій не виконується на певному рівні.

Перевагою цих показників преміювання $€$ об'єктивність, оскільки вони кількісні й встановлюються на підставі даних облікових систем. Вони дають можливість оцінити затрати трудових зусиль медичних працівників та підвищити неконкурентоспроможну заробітну плату медичних працівників первинної ланки. Однак їх застосування на сучасному етапі суперечить деяким критеріям ефективного преміювання [35, С. 569-574]: нараховуються за результати та діяльність працівників, що $\epsilon$ обов'язковими й оплачуються в межах постійної (тарифної) частини заробітної плати; не відповідають актуальним завданням, що стоять перед Центрами та їх персоналом, оскільки більшість лікарів за майже два роки укладання декларацій уже виконала норму залучення пацієнтів, натомість якість надання первинної медичної допомоги потребує підвищення.

Поряд з об'єктивними показниками преміювання у колективних договорах майже всіх Центрів вказується дуже багато абстрактних 
напрямів преміювання, які не конкретизовані у вигляді показників, а рішення про преміювання за цими напрямами суб'єктивно приймають керівники Центрів. Наявність таких елементів в системах преміювання Центрів порушує такі вимоги до ефективного преміювання [35, С. 569-574], як обмеження кількості показників і умов преміювання; необхідність визначати вихідну величину показників і умов преміювання та передбачати «технологію» встановлення їх фактичного рівня, що дає підставу для сплати винагороди. В межах цієї групи показників і умов преміювання варто окремо назвати преміювання до ювілейних дат та професійних свят, яке не зумовлене трудовими зусиллями або результатами діяльності і в силу широкого охоплення працівників не $\epsilon$ стимулом для збільшення кількості та якості праці [35, С. 569-574].

Наявність в деяких колективних договорах показників і умов преміювання, які відповідають завданням, що стоять перед первинною ланкою охорони здоров'я [35, С. 569-574], можна назвати позитивною характеристикою преміювання медичних працівників. Однак кількість Центрів ПМД, де вони застосовуються, дуже мала, та й перелік застосованих показників значно вужчий ніж показники якості первинної медичної допомоги. Зокрема, взагалі не застосовуються наступні:

- показник виконання плану проведення флюорографічного обстеження групи медичного ризику;

- показник виконання календарного плану проведення обов'язкових медичних профілактичних оглядів здорової дитини віком до трьох років;

- показник рівня первинної захворюваності на гострий інфаркт міокарда та гострий інсульт серед населення працездатного віку на 1 тис. осіб прикріпленого населення відповідного віку;

- показник рівня госпіталізації до 303, які надають вторинну (спеціалізовану) медичну допомогу в стаціонарних умовах, на 100 осіб прикріпленого населення;

- показник кількості виїздів за викликами екстреної медичної допомоги до хронічних хворих на 1 тис. осіб прикріпленого населення;

- показник кількості консультативних висновків з приводу захворювання, наданих лікарем вторинної (спеціалізованої) медичної допомоги в амбулаторних умовах, на 1 тис. осіб прикріпленого населення [36];

- показник виконання календарного плану проведення обов'язкових медичних профілактичних оглядів для груп пацієнтів 3 підвищеним ризиком розвитку захворювань на гіпертонічну хворобу 
та інші серцево-судинні захворювання, цукровий діабет, рак молочної залози, колоректальний рак, рак передміхурової залози [37].

Натомість стимулювання медичних працівників первинної ланки вчасно виявляти зазначені та інші захворювання, здійснювати їх профілактику є надзвичайно актуальним завданням, оскільки рівень захворюваності населення України у 2017 році порівняно 3 1995 значно зріс. Зокрема, кількість випадків уперше виявлених хвороб кругообігу збільшилася у понад 1,55 рази (з 2710 до 4208 випадків на 100 тис. населення), новоутворень - в 1,17 рази (з 639 до 746 випадків на 100 тис. населення). Крім того, рівень захворювання населення України $€$ значно вищим порівняно із розвиненими країнами [14, С. 35].

Щоб подолати зазначені недоліки в системі преміювання медичних працівників центрів надання первинної медичної допомоги, пропонується:

1) змінити кваліфікування премії за укладені декларації лікарів та медичних сестер, що з ними працюють, у підвищення посадового окладу, що дасть змогу підвищити його конкурентоспроможність на ринку праці i, одночасно, не порушувати сутність преміювання взаємозв'язок показників преміювання із цілями і завданнями, які стоять перед охороною здоров'я загалом і медичним підприємством зокрема [35, С. 569-574];

2) здійснювати преміювання медичних працівників за ключовими показниками ефективності (Key Performance Indicators, КРІ, КПЕ) - кількісними показниками, за якими можна виміряти рівень досягнення цілей, визначених у стратегічних документах розвитку системи, організації, структурного підрозділу, працівника [38].

Показники преміювання мають відповідати таким критеріям [9]: достовірність, надійність, специфічність, чутливість, фінансова доступність, здійсненність, вимірюваність, можливість порівняння. 3 огляду на високу прогресуючу захворюваність населення та цілі розвитку охорони здоров'я в Україні як КПЕ галузі, медичних підприємств та окремих медичних працівників варто визначати показники якості надання медичних послуг. Їх перелік спочатку встановлюється для конкретного закладу охорони здоров'я залежно від ситуації із захворюваністю населення, що обслуговується, а потім для працівників різних груп залежно від можливостей впливу на якість медичних послуг. Вибрати показники можна із наявної нормативно-правової бази щодо ПМД або практичних консультацій [36; 37; 39], найвагоміші з яких: 
- рівень вакцинопрофілактики;

- рівень грудного вигодовування;

- ведення вкладки «Фактори ризику» в картці пацієнта;

- проактивний контакт із окремими групами пацієнтів;

- ведення групових занять для пацієнта (школи пацієнтів).

Для уточнення показників ефективності, визначення їх вагомості варто опитувати самих медичних працівників. В результаті не тільки може бути зібрана цінна експертна інформація, а й покращиться поінформованість медичних працівників про умови преміювання та встановлення їх значимості для розвитку КНП, а відтак мотивованість працівників досягати стратегічних цілей його розвитку [38].

Розраховувати премію конкретного медичного працівника на основі КПЕ можна двома альтернативними способами. Перший спосіб пропонується у [11, С. 16; 39, С. 137] - премія визначається керівником КНП у відсотках (k) до посадового окладу (ПО), помноженого на суму КПЕ $\left(\Sigma K \Pi E_{B}\right)$, скоригованих на вагу відповідного КПЕ (Bi):

$$
\begin{aligned}
& \Pi_{\mathrm{K \Pi Е}}=\mathrm{k} \cdot \Pi \mathrm{O} \cdot \sum \mathrm{K \Pi Е}_{\mathrm{B}}, \\
& \mathrm{K \Pi Е}_{\mathrm{B}}=\mathrm{K \Pi E}_{\mathrm{i}} \cdot \mathrm{B}_{\mathrm{i}},
\end{aligned}
$$

де $\mathrm{KПE}_{\mathrm{i}}$ - фактичне значення кожного КПЕ за період оцінки (наприклад, квартал).

Перший спосіб простий, але, застосовуючи його, можна наразитися на перевищення рамок бюджету КНП або встановлення невідчутних стимулів для працівника. Тому, щоб уникнути такого ризику, краще, щоб керівництво КНП спочатку встановлювало відсоток преміального фонду від надходжень до закладу за категоріями працівників та фіксувало його у колективному договорі, а уже потім розподіляло фонди за категоріями працівників відповідно до індивідуального внеску кожного, визначеного на основі КПЕ, як це запропоновано у [38]. Відповідно премія, що підлягає виплаті i-ому медичному працівнику за ј-тим показником результативності визначаються за формулою

$$
\Pi i j=\Phi \Pi \cdot N i j,
$$

де ФП - преміальний фонд працівників певної категорії;

$N_{i j}$ - нормоване значення КПЕ:

$$
N i j=\frac{\mathrm{B} i j}{\mathrm{~B} i j},
$$

де $B i j=j P i j$ - зважене перевищення фактичного значення КПЕ $\left(\Phi_{i j}\right)$ над нормативним $\left(H_{j}\right)$ - середнім, $\gamma_{j}$ - вагомість КПЕ. 
Перевищення значень показника результативності визначається за аналогією з «темпом приросту»:

- для стимуляторів (показників, що характеризують позитивні результати діяльності, які мають бути максимізовані)

$$
P i j=\frac{\Phi i j}{H j}-1
$$

- для дестимуляторів (показників, що характеризують негативні результати діяльності, які мають бути мінімізовані)

$$
P i j=1-\frac{\Phi i j}{H j} \text {. }
$$

Розрахунок премії пропонується здійснювати в табличній формі в програмному середовищі Excel (табл. 2).

Таблиця 2

Таблиця для розрахунку премії працівнику Центру ПМД

\begin{tabular}{|c|c|c|c|c|c|c|}
\hline $\begin{array}{c}\text { № } \\
\text { п-ка }\end{array}$ & $\begin{array}{c}\text { Значимість } \\
\text { показника } \\
\text { працівника } \\
(ү j), \%\end{array}$ & $\begin{array}{c}\text { Нормативне } \\
\text { значення } \\
\text { показника } \\
\text { (Нj) }\end{array}$ & $\begin{array}{c}\text { Фактичне } \\
\text { значення } \\
\text { показника } \\
(Ф і \mathrm{ij})\end{array}$ & $\begin{array}{c}\text { Перевищення } \\
\text { Фіj над Нij } \\
\text { (Bij) }\end{array}$ & $\begin{array}{c}\text { Нормоване } \\
\text { значення } \\
(\mathrm{Nij})\end{array}$ & $\begin{array}{c}\text { Премія } \\
(\text { (Пij) }\end{array}$ \\
\hline 1 & & & & & & \\
\hline$\ldots$ & & & & & & \\
\hline не більше 5 & & & & & & \\
\hline Разом & 100 & $X$ & $X$ & & $X$ & \\
\hline
\end{tabular}

(розроблено авторами)

В результаті розрахунків ті працівники, які мають перевищення хоча б одного КПЕ у порівнянні з нормативним рівнем, зможуть отримати премію. Водночас ті, які мають нижчі показники за середні у КНП не зможуть отримати премію.

Висновки. Удосконалена система преміювання медичних працівників 3 урахуванням ключових показників ефективності дозволить посилити їх мотивацію до покращення якості надання первинної медичної допомоги в Україні та зменшення захворюваності населення.

1. Національна стратегія реформування системи охорони здоров'я в Україні на період 2015-2020 років. 41 c. URL: https://moz.gov.ua/uploads/0/691-strategiya.pdf (дата звернення: 08.12.2020). 2. М03 України: що було, є і буде. 68 с. URL: https://moz.gov.ua/uploads/2/13773-transition_book_healthcare.pdf. (дата звернення: 08.12.2020). 3. Короленко В. В., Юрочко Т. П. Кадрова політика у сфері охорони здоров'я України в контексті європейської інтеграції. К., 2018. 96 с. URL: http://ekmair.ukma.edu.ua/bitstream/handle/123456789/15804/Korolenko_Kadrova_ polityka_u_sferi_okhorony_zdorovia_Ukrainy_v_konteksti_yevropeiskoi.pdf?sequence $=1$ \&isAllowed =y. (дата звернення: 08.12.2020). 4. Авраменко Т. П. Кадрова політика у реформуванні сфери охорони здоров'я : аналіт. доп. К. : НICД, 2012. 35 с. URL: 
https://niss.gov.ua/sites/default/ files/2012-12/health-a1e6b.pdf (дата звернення: 08.12.2020). 5. Гуцалюк О. М. Аналіз стану кадрового забезпечення сфери охорони здоров'я України у період реформування. Вісник економічної науки України. 2019. № 2 (37). C. 110-114. URL: http://www.venu-journal.org/ download/2019/2/19Hutsaliuk.pdf (дата звернення: 08.12.2020). 6.Державне управління реформуванням системи охорони здоров'я в Україні : навч.-наук. вид. / авт. кол. : М. М.Білинська, Я.Ф.Радиш, І.В. Рожкова та ін. ; за заг. ред. проф. М. М. Білинської. К. ; Львів: НАДУ, 2012. 240 с. URL: http://academy.gov.ua/NMKD/library_nadu/Biblioteka_Magistra/ 2a68618e-77794d59-829b-fab7a50af196.pdf. (дата звернення: 08.12.2020). 7. Коломоєць А. В., Толстанов О. К., Гбур З. В. Кадрова складова як частина ефективної логістики медичного закладу. Український журнал медицини, біології та спорту. 2020. Том 5, № 3 (25). C. 304-311. URL: https://jmbs.com.ua/pdf/5/3/jmbs0-2020-5-3-304.pdf (дата звернення: 08.12.2020). 8. Кравчук І. І., Присяжнюк О. Ф., Веселовський О. Б. Удосконалення управління персоналом закладів охорони здоров'я. Ефективна економіка. 2020. № 2. URL: http://www.economy.nayka.com.ua/ pdf/2_2020/3.pdf (дата звернення: 08.12.2020). 9. Кадрові ресурси системи охорони здоров'я в Україні. Ситуаційний аналіз / Д. Богдан, А. Бойко, А. Василькова та ін. Проект USAID «Підтримка реформи охорони здоров'я». Київ, 2019. 133 с. URL: https://www.skeptic.in.ua/wp-content/uploads/HRH-situational-analysis-2019.pdf. (дата звернення: 08.12.2020). 10. Методичні рекомендації та роз'яснення з питань укладення колективних договорів комунальних некомерційних підприємств. Проект USAID «Підтримка реформи охорони здоров'я». Київ, 2020. 72 с. URL: https://moz.gov.ua/uploads/3/19289-b_coll_dogovor_ua_v105_03_03_2020.pdf. (дата звернення: 08.12.2020). 11. Галушко О., Слабкий Г.О. Керівництво із застосування схем стимулювання медичних працівників у сфері надання ВІЛ-послуг. ТОВ «Делойт Консалтінг», $2018.26 \mathrm{c} . \quad$ URL: https://dspace.uzhnu.edu.ua/jspui/handle/lib/20717. (дата звернення: 08.12.2020). 12. Національна служба здоров'я України. Електронна карта місць надання первинної медичної допомоги. URL: https://nszu.gov.ua/e-data/dashboard/pmd-map (дата звернення: 01.12.2020). 13. Статистичний щорічник України за 2019 рік. К. : Державна служба статистики України, 2020. 465 с. URL: http://www.ukrstat.gov.ua/druk/publicat/kat_u/2020/zb/11/zb_yearbook_2019.pdf. (дата звернення: 08.12.2020). 14. Заклади охорони здоров'я та захворюваність населення України у 2017 році. Статистичний збірник. К.: Державна служба статистики України, 2018.2109 с. URL: http://www.ukrstat.gov.ua/druk/publicat/kat_u/2018/zb/06/zb_zoz_17.pdf. (дата звернення: 08.12.2020). 15. Колективний договір укладений між адміністрацією КНП «Центр ПМСД № 3 Дарницького району м. Києва» та первинною профспілковою організацією КНП «Центр ПМСД № 3 Дарницького району м. Києва» від 23.09.2020 p. URL: https://darn.kyivcity.gov.ua/files/2020/10/16/3.PDF (дата звернення: 08.12.2020). 16. Зміни та доповнення до Колективного договору КНП «Центр ПМСД № 1» Святошинського району м. Києва на 2020-2024. URL: https://svyat.kyivcity.gov.ua/files/2020/2/10/KD_KNP_CPMSD_1.pdf (дата звернення: 08.12.2020). 17. Колективний договір укладений між КНП «Тульчинський центр ПМСД» Тульчинської міської ради та Первинною профспілковою організацією КНП «Тульчинський центр ПМСД» Тульчинської міської ради на 2019-2022рp. URL: https://rada.info/upload/users_files/42447462/docs/9db41d6a7334075905b969f759 4c88d7.pdf (дата звернення: 08.12.2020). 18. Колективний договір між Адміністрацією та Радою трудового колективу КП «Козятинський міський центр 
Серія «Економічні науки»

Випуск 4(92) 2020 p.

ПМСД Козятинської міської ради» на 2020-2021 роки. URL: https://komr.gov.ua/download_file_id/40203 (дата звернення: 08.12.2020). 19. Колективний договір між головним лікарем КНП «Центр ПМСД Покровської міської ради Дніпропетровської області»та первинною профспілковою організацією КНП «Центр ПМСД Покровської міської ради Дніпропетровської області» від 06.05 .2020 p. https://pkrv.dp.gov.ua/documents/download/5_cpmsd_koldog_aace59dcf9cd5ea7741 efb2c51312196.pdf (дата звернення: 08.12.2020). 20. Колективний договір між адміністрацією КНП «Центр ПМСД Мар'їнської районної ради» та профспілковим комітетом первинної профспілкової організації КНП «Центр ПМСД Мар"їнської районної ради» на 2020-2025 роки. URL: http://mar.gov.ua/wpcontent/uploads $/ 2019 / 10 / \mathrm{kol}$-dog-KNP-CPMSD_compressed.pdf (дата звернення: 08.12.2020). 21. Зміни до Колективного договору між адміністрацією та трудовим колективом КНП Маріупольської міської ради «Центр ПМСД № 5 м. Маріуполя на 2018-2023 роки. URL: https://cutt.ly/Ojam41Q. (дата звернення: 08.12.2020). 22. Колективний договір між адміністрацією та трудовим колективом КНП «Центр ПМСД Полянської сільської ради Свалявського району Закарпатської області» на 2018-2023 роки.

URL: https://rada.info/upload/users_files/04351587/821b4c268c54b56c3848da13bf862a1 4.pdf (дата звернення: 08.12.2020). 23. Зміни та доповнення до Колективного договору між КНП «Центр ПМСД № 2» та профспілковим комітетом КНП «Центр ПМСД № 2» на 2019-2021 роки. URL: https://zp.gov.ua/upload/editor/263_knp_cpmsd_2.PDF_ (дата звернення: 08.12.2020). 24. Колективний договір між адміністрацією та профспілковим комітетом КНП Коломийської міської ради «Коломийський міський центр ПМСД» та незалежною профспілкою на 2021-2024 роки. URL: https://cutt.ly/2ja08xF (дата звернення: 08.12.2020). 25. Колективний договір укладений між адміністрацією КНП Бородянської районної ради «Бородянський центр ПМСД» та представниками трудового колективу КНП Бородянської районної ради «Бородянський центр ПМСД» на 2020-2023 роки. URL: https://bsr.gov.ua/wpcontent/uploads/2020/09/kolektyvnyj-dohovir-tspmsd.pdf (дата звернення: 08.12.2020). 26. Колективний договір між адміністрацією та трудовим колективом КНП «Чорнухинський центр ПМСД» Чорнухинської районної ради на 2019-2023 роки. URL: https://chorn.pmsd.org.ua/wp-content/uploads/2019/09/novyj-2019.pdf (дата звернення: 08.12.2020). 27. Зміни до Колективного договору між адміністрацією та профспілковим комітетом КНП «Центр ПМСД «Ювілейний» Рівненської міської ради на 2015-2020 роки. URL: https://rivnesoc.gov.ua/wpcontent/uploads/2019/12/zminy-czpmsd-yuvilejnyj.pdf (дата звернення: 08.12.2020). 28. Зміни до Колективного договору між адміністрацією та профспілковим комітетом КНП «Центр ПМСД «Північний» Рівненської міської ради на 2018-2023 роки. URL: https://rivnesoc.gov.ua/wp-content/uploads/2020/01/zminy_czpmsdpivnichnyj.pdf (дата звернення: 08.12.2020). 29. Колективний договір між адміністрацією та профспілковим комітетом КНП «Березнівський районний центр ПМД» Березнівської районної ради на 2020-2025 роки. URL: http://brrda.gov.ua/socialnij-zahist/reyestr-kolektivnih-dogovoriv-zmin-i-dopovnendo-n/ (дата звернення: 08.12.2020). 30. Колективний договір між адміністрацією i профспілковим комітетом КНП «Володимирецький районний центр ПМСД» Володимирецької районної ради на 2019-2021 роки. URL: http://www.volpmcd.rv.ua/wp-content/uploads/2019/08/kolektivnij-dogovir-pmsdna-2019-2021r.doc. (дата звернення: 08.12.2020). 31. Колективний договір між 
КНП «Краснопільський районний центр ПМСД» Краснопільської районної ради та представниками робочого колективу КНП «Краснопільський районний центр ПМСД» Краснопільської районної ради від 07.08.2018 p. URL: http://krascentr.pmsd.org.ua/wp-content/uploads/2018/10/Kolektyvnyj-dogovir-2.pdf. (дата звернення: 08.12.2020). 32. Колективний договір КНП «Нижньосірогозький центр ПМСД» на 2020-2023 роки. URL: https://rda.n-sirog.gov.ua/wpcontent/uploads/2020/07/KD-8-KNP-Nyzhnosirogozkyj-tsentr-pervynnoyi-medykosanitarnoyi-dopomogy-.pdf (дата звернення: 08.12.2020). 33. Зміни та доповнення до колективного договору між адміністрацією і профспілковим комітетом КНП «Центр ПМСД Білозерського району» на 2017-2020 роки. URL: http://bilozerkarda.gov.ua/wp-content/uploads/2020/01/Zmini-do-koldogovoru-KNP-TSPMSD.docx (дата звернення: 08.12.2020). 34. Зміни та доповнення до колективного договору між адміністрацією та трудовим колективом КНП «Центр ПМСД» Смілянської міської ради на 2019-2024 роки. URL: https://smilarada.gov.ua/sites/default/files/knp_cenr_mediko_san_dop.pdf (дата звернення: 08.12.2020). 35. Економіка праці та соціально-трудові відносини : підручник / А. М. Колот, О. А. Грішнова, О.О. Герасименко та ін. ; за наук. ред. д-ра екон. наук, проф. А. М. Колота. К. : КНЕУ, 2009. 711 с. 36. Порядок встановлення надбавок за обсяг та якість виконаної роботи медичним працівникам закладів охорони здоров'я, що надають первинну медичну допомогу : затверджено Постановою Кабінету Міністрів України від 30 грудня 2013 р. № 977. Дата оновлення: 15.04.2014. URL: https://zakon.rada.gov.ua/laws/show/977-2013-\%D0\%BF\#Text. (дата звернення: 15.12.2020). 37. Порядок надання первинної медичної допомоги : затверджено наказом Міністерства охорони здоров'я України 19 березня 2018 року № 504. Дата оновлення: 12.12.2020. URL: https://moz.gov.ua/uploads/0/4207dn_20180319_504.pdf. (дата звернення: 15.12.2020). 38. Рощик I. А., Овсіюк М. В. Ключові показники результативності як основа мотивації працівників центрів надання адміністративних послуг. 2019. Вісник НУВГП. Вип. 4(88). С. 253-267. URL: http://ep3.nuwm.edu.ua/17913/ (дата звернення: 08.12.2020). 39. Центри передового досвіду первинної медичної допомоги : посібник / Проект USAID «Підтримка реформи охорони здоров'я». Київ, 2020. URL: http://healthreform.in.ua/wp-content/uploads/2020/02/COEs-manual_for-PHCweb.pdf (дата звернення: 08.12.2020).

\section{REFERENCES:}

1. Natsionalna stratehiia reformuvannia systemy okhorony zdorovia $v$ Ukraini na period 2015-2020 rokiv. 41 s. URL: https://moz.gov.ua/uploads/0/691-strategiya.pdf (data zvernennia: 08.12.2020). 2. MOZ Ukrainy: shcho bulo, ye i bude. 68 s. URL: https://moz.gov.ua/uploads/2/13773-transition_book_healthcare.pdf (data zvernennia: 08.12.2020). 3. Korolenko V. V., Yurochko T. P. Kadrova polityka u sferi okhorony zdorovia Ukrainy $v$ konteksti yevropeiskoi intehratsii. K., 2018. 96 s. URL: http://ekmair.ukma.edu.ua/bitstream/handle/123456789/15804/Korolenko_Kadrova_ polityka_u_sferi_okhorony_zdorovia_Ukrainy_v_konteksti_yevropeiskoi.pdf?sequence $=1$ \&isAllowed=y (data zvernennia: 08.12.2020). 4. Avramenko T. P. Kadrova polityka u reformuvanni sfery okhorony zdorovia : analit. dop. K. : NISD, 2012. 35 s. URL: https://niss.gov.ua/sites/default/ files/2012-12/health-a1e6b.pdf. (data zvernennia: 08.12.2020). 5. Hutsaliuk O. M. Analiz stanu kadrovoho zabezpechennia sfery okhorony zdorovia Ukrainy u period reformuvannia. Visnyk ekonomichnoi nauky Ukrainy. 2019. № 2 (37). S. 110-114. URL: http://www.venu-journal.org/ download/2019/2/19Hutsaliuk.pdf (data zvernennia: 08.12.2020). 6. Derzhavne upravlinnia 
reformuvanniam systemy okhorony zdorovia v Ukraini : navch.-nauk. vyd. / avt. kol. : M. M. Bilynska, Ya. F. Radysh, I. V. Rozhkova ta in. ; za zah. red. prof. M. M. Bilynskoi. K. ; Lviv: $\quad$ NADU, $2012 . \quad 240 \quad$ S. http://academy.gov.ua/NMKD/library_nadu/Biblioteka_Magistra/ 2a68618e-77794d59-829b-fab7a50af196.pdf (data zvernennia: 08.12.2020). 7. Kolomoiets A. V., Tolstanov 0. K., Hbur Z. V. Kadrova skladova yak chastyna efektyvnoi lohistyky medychnoho zakladu. Ukrainskyi zhurnal medytsyny, biolohii ta sportu. 2020. № 3 (25). Tom 5. S. 304-311. URL: https://jmbs.com.ua/pdf/5/3/jmbs0-2020-5-3-304.pdf (data zvernennia: 08.12.2020). 8. Kravchuk I. I., Prysiazhniuk O. F., Veselovskyi O. B. Udoskonalennia upravlinnia personalom zakladiv okhorony zdorovia. Efektyvna ekonomika. 2020. № 2. URL: http://www.economy.nayka.com.ua/ pdf/2_2020/3.pdf (data zvernennia: 08.12.2020). 9. Kadrovi resursy systemy okhorony zdorovia $v$ Ukraini. Sytuatsiinyi analiz / D. Bohdan, A. Boiko, A. Vasylkova ta in. Proekt USAID «Pidtrymka reformy okhorony zdorovia». Kyiv, 2019. 133 s. URL: https://www.skeptic.in.ua/wp-content/uploads/HRH-situational-analysis-2019.pdf (data zvernennia: 08.12.2020). 10. Metodychni rekomendatsii ta roziasnennia z pytan ukladennia kolektyvnykh dohovoriv komunalnykh nekomertsiinykh pidpryiemstv. Proekt USAID «Pidtrymka reformy okhorony zdorovia». Kyiv, 2020. 72 s. URL: https://moz.gov.ua/uploads/3/19289-b_coll_dogovor_ua_v105_03_03_2020.pdf (data zvernennia: 08.12.2020). 11. Halushko 0., Slabkyi H.O. Kerivnytstvo iz zastosuvannia skhem stymuliuvannia medychnykh pratsivnykiv u sferi nadannia VIL-posluh. TOV «Deloit Konsaltinh», $2018 . \quad 46 \mathrm{~s} . \quad$ URL: https://dspace.uzhnu.edu.ua/jspui/handle/lib/20717 (data zvernennia: 08.12.2020). 12. Natsionalna sluzhba zdorovia Ukrainy. Elektronna karta mists nadannia pervynnoi medychnoi dopomohy. URL: https://nszu.gov.ua/e-data/dashboard/pmd-map (data zvernennia: 01.12.2020). 13. Statystychnyi shchorichnyk Ukrainy za 2019 rik. K. : Derzhavna sluzhba statystyky Ukrainy, 2020. 465 s. URL: http://www.ukrstat.gov.ua/druk/publicat/kat_u/2020/zb/11/zb_yearbook_2019.pdf (data zvernennia: 08.12.2020). 14. Zaklady okhorony zdorovia ta zakhvoriuvanist naselennia Ukrainy u 2017 rotsi. Statystychnyi zbirnyk. K. : Derzhavna sluzhba statystyky Ukrainy, $2018 . \quad 109 \quad$ s. http://www.ukrstat.gov.ua/druk/publicat/kat_u/2018/zb/06/zb_zoz_17.pdf (data zvernennia: 08.12.2020). 15. Kolektyvnyi dohovir ukladenyi mizh administratsiieiu KNP «Tsentr PMSD № 3 Darnytskoho raionu m. Kyieva» ta pervynnoiu profspilkovoiu orhanizatsiieiu KNP «Tsentr PMSD № 3 Darnytskoho raionu m. Kyieva» vid 23.09.2020 r. URL: https://darn.kyivcity.gov.ua/files/2020/10/16/3.PDF (data zvernennia: 08.12.2020). 16. Zminy ta dopovnennia do Kolektyvnoho dohovoru KNP «Tsentr PMSD № 1» Sviatoshynskoho raionu $m$. Kyieva na 2020-2024. URL: https://svyat.kyivcity.gov.ua/files/2020/2/10/KD_KNP_CPMSD_1.pdf (data zvernennia: 08.12.2020). 17. Kolektyvnyi dohovir ukladenyi mizh KNP «Tulchynskyi tsentr PMSD» Tulchynskoi miskoi rady ta Pervynnoiu profspilkovoiu orhanizatsiieiu KNP «Tulchynskyi tsentr PMSD» Tulchynskoi miskoi rady na 2019-2022 rr. URL: https://rada.info/upload/users_files/42447462/docs/9db41d6a7334075905b969f759 4c88d7.pdf (data zvernennia: 08.12.2020). 18. Kolektyvnyi dohovir mizh Administratsiieiu ta Radoiu trudovoho kolektyvu KP «Koziatynskyi miskyi tsentr PMSD Koziatynskoi miskoi rady» na 2020-2021 roky. URL: https://komr.gov.ua/download_file_id/40203 (data zvernennia: 08.12.2020). 19. Kolektyvnyi dohovir mizh holovnym likarem KNP «Tsentr PMSD Pokrovskoi miskoi rady Dnipropetrovskoi oblasti»ta pervynnoiu profspilkovoiu orhanizatsiieiu KNP «Tsentr PMSD Pokrovskoi miskoi rady Dnipropetrovskoi oblasti» vid 06.05.2020 r. URL:

https://pkrv.dp.gov.ua/documents/download/5_cpmsd_koldog_aace59dcf9cd5ea7741efb 2c51312196.pdf (data zvernennia: 08.12.2020). 20. Kolektyvnyi dohovir mizh 
administratsiieiu KNP «Tsentr PMSD Marinskoi raionnoi rady» ta profspilkovym komitetom pervynnoi profspilkovoi orhanizatsii KNP «Tsentr PMSD Marinskoi raionnoi rady» na 2020-2025 roky. URL: http://mar.gov.ua/wp-content/uploads/2019/10/koldog-KNP-CPMSD_compressed.pdf (data zvernennia: 08.12.2020). 21. Zminy do Kolektyvnoho dohovoru mizh administratsiieiu ta trudovym kolektyvom KNP Mariupolskoi miskoi rady «Tsentr PMSD № 5 m. Mariupolia na 2018-2023 roky. URL: https://cutt.ly/Ojam41Q (data zvernennia: 08.12.2020). 22. Kolektyvnyi dohovir mizh administratsiieiu ta trudovym kolektyvom KNP «Tsentr PMSD Polianskoi silskoi rady Svaliavskoho raionu Zakarpatskoi oblasti» na 2018-2023 roky. URL: https://rada.info/upload/users_files/04351587/821b4c268c54b56c3848da13bf862a1 4.pdf (data zvernennia: 08.12.2020). 23. Zminy ta dopovnennia do Kolektyvnoho dohovoru mizh KNP «Tsentr PMSD № 2» ta profspilkovym komitetom KNP «Tsentr PMSD № 2» na 2019-2021 roky. https://zp.gov.ua/upload/editor/263_knp_cpmsd_2.PDF (data zvernennia: 08.12.2020). 24. Kolektyvnyi dohovir mizh administratsiieiu ta profspilkovym komitetom KNP Kolomyiskoi miskoi rady «Kolomyiskyi miskyi tsentr PMSD» ta nezalezhnoiu profspilkoiu na 2021-2024 roky. URL: https://cutt.ly/2ja08xF (data zvernennia: 08.12.2020). 25. Kolektyvnyi dohovir ukladenyi mizh administratsiieiu KNP Borodianskoi raionnoi rady «Borodianskyi tsentr PMSD» ta predstavnykamy trudovoho kolektyvu KNP Borodianskoi raionnoi rady «Borodianskyi tsentr PMSD» na 2020-2023 roky. URL: https://bsr.gov.ua/wp-content/uploads/2020/09/kolektyvnyj-dohovirtspmsd.pdf (data zvernennia: 08.12.2020). 26. Kolektyvnyi dohovir mizh administratsiieiu ta trudovym kolektyvom KNP «Chornukhynskyi tsentr PMSD» Chornukhynskoi raionnoi rady na 2019-2023 roky. URL: https://chorn.pmsd.org.ua/wp-content/uploads/2019/09/novyj-2019.pdf (data zvernennia: 08.12.2020). 27. Zminy do Kolektyvnoho dohovoru mizh administratsiieiu ta profspilkovym komitetom KNP «Tsentr PMSD «luvileinyi» Rivnenskoi miskoi rady na 2015-2020 roky. URL: https://rivnesoc.gov.ua/wp-content/uploads/2019/12/zminyczpmsd-yuvilejnyj.pdf (data zvernennia: 08.12.2020). 28. Zminy do Kolektyvnoho dohovoru mizh administratsiieiu ta profspilkovym komitetom KNP «Tsentr PMSD «Pivnichnyi» Rivnenskoi miskoi rady na 2018-2023 roky. URL: https://rivnesoc.gov.ua/wp-content/uploads/2020/01/zminy_czpmsd-pivnichnyj.pdf (data zvernennia: 08.12.2020). 29. Kolektyvnyi dohovir mizh administratsiieiu ta profspilkovym komitetom KNP «Bereznivskyi raionnyi tsentr PMD» Bereznivskoi raionnoi rady na 2020-2025 roky. URL: http://brrda.gov.ua/socialnij-zahist/reyestrkolektivnih-dogovoriv-zmin-i-dopovnen-do-n/ (data zvernennia: 08.12.2020). 30. Kolektyvnyi dohovir mizh administratsiieiu i profspilkovym komitetom KNP «Volodymyretskyi raionnyi tsentr PMSD» Volodymyretskoi raionnoi rady na 2019-2021 roky URL: http://www.volpmcd.rv.ua/wp-content/uploads/2019/08/kolektivnijdogovir-pmsd-na-2019-2021r.doc (data zvernennia: 08.12.2020). 31. Kolektyvnyi dohovir mizh KNP «Krasnopilskyi raionnyi tsentr PMSD» Krasnopilskoi raionnoi rady ta predstavnykamy robochoho kolektyvu KNP «Krasnopilskyi raionnyi tsentr PMSD» Krasnopilskoi raionnoi rady vid 07.08.2018 r. URL: http://kras-centr.pmsd.org.ua/wpcontent/uploads/2018/10/Kolektyvnyj-dogovir-2.pdf (data zvernennia: 08.12.2020). 32. Kolektyvnyi dohovir KNP «Nyzhnosirohozkyi tsentr PMSD» na 2020-2023 roky. URL: $\quad$ https://rda.n-sirog.gov.ua/wp-content/uploads/2020/07/KD-8-KNPNyzhnosirogozkyj-tsentr-pervynnoyi-medyko-sanitarnoyi-dopomogy-.pdf (data zvernennia: 08.12.2020). 33. Zminy ta dopovnennia do kolektyvnoho dohovoru mizh administratsiieiu i profspilkovym komitetom KNP «Tsentr PMSD Bilozerskoho raionu» na 2017-2020 roky. URL: http://bilozerka-rda.gov.ua/wpcontent/uploads/2020/01/Zmini-do-koldogovoru-KNP-TSPMSD.docx (data zvernennia: 08.12.2020). 34. Zminy ta dopovnennia do kolektyvnoho dohovoru mizh administratsiieiu ta trudovym kolektyvom KNP «Tsentr PMSD» Smilianskoi miskoi 
Серія «Економічні науки»

Випуск 4(92) 2020 p.

rady na 2019-2024 roky. URL: https://smilarada.gov.ua/sites/default/files/knp_cenr_mediko_san_dop.pdf (data zvernennia: 08.12.2020). 35. Ekonomika pratsi ta sotsialno-trudovi vidnosyny : pidruchnyk / A. M. Kolot, 0. A. Hrishnova, 0. 0. Herasymenko ta in. ; za nauk. red. d-ra ekon. nauk, prof. A. M. Kolota. K. : KNEU, 2009. 711 s. 36. Poriadok vstanovlennia nadbavok za obsiah ta yakist vykonanoi roboty medychnym pratsivnykam zakladiv okhorony zdorovia, shcho nadaiut pervynnu medychnu dopomohu : zatverdzheno Postanovoiu Kabinetu Ministriv Ukrainy vid 30 hrudnia 2013 r. № 977. Data onovlennia: 15.04.2014. URL: $\quad$ https://zakon.rada.gov.ua/laws/show/977-2013-\%D0\%BF\#Text (data zvernennia: 15.12.2020). 37. Poriadok nadannia pervynnoi medychnoi dopomohy : zatverdzheno nakazom Ministerstva okhorony zdorovia Ukrainy 19 bereznia 2018 roku № 504. Data onovlennia: 12.12.2020. URL: https://moz.gov.ua/uploads/0/4207dn_20180319_504.pdf (data zvernennia: 15.12.2020). 38. Roshchyk I. A., Ovsiiuk M. V. Kliuchovi pokaznyky rezultatyvnosti yak osnova motyvatsii pratsivnykiv tsentriv nadannia administratyvnykh posluh. 2019. Visnyk NUVHP. Vyp. 4(88). S. 253-267. URL: http://ep3.nuwm.edu.ua/17913/ (data zvernennia: 08.12.2020). 39. Tsentry peredovoho dosvidu pervynnoi medychnoi dopomohy : posibnyk / Proekt USAID «Pidtrymka reformy okhorony zdorovia». Kyiv, $2020 . \quad$ URL: http://healthreform.in.ua/wp-content/uploads/2020/02/COEs-manual_for-PHCweb.pdf (data zvernennia: 08.12.2020).

Roshchyk I. A. [1; ORCID ID: 0000-0002-3155-2727], Candidate of Economics (Ph.D.), Associate Professor,

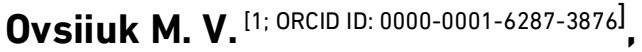
Graduate Student

${ }^{1}$ National University of Water and Environmental Engineering, Rivne

\section{INCENTIVES FOR MEDICAL STAFF IN PRIMARY MEDICAL CARE CENTERS}

Based on the analysis of collective agreements of primary health care centers, the main characteristics of the system of bonuses for medical staff are established. The most common main indicators of incentives for doctors and nurses who make declarations with patients (income from declarations and the bonus of a doctor working in a team) are objective, as they are quantitative and based on data from accounting systems, but are calculated based on results and activities of employees that are mandatory and paid within the permanent (tariff) part of the salary, and do not meet the current tasks facing the Centers and their staff - improving the quality of primary health care. Along with them, abstract areas of incentives are used, there are many of them, some of them are not due to labor or performance, and the "technology" of determining on the basis of their remuneration is uncertain. Despite the high and progressive morbidity of the population, medical staff is very rarely rewarded (depressed) for the performance indicators of the primary health care quality.

To eliminate these shortcomings of the medical staff bonus systems, it is proposed to transform them: 1) to reclassify the bonuses for the concluded declarations of doctors and nurses who work with them into a 
salary increase; 2) implement indicators of the quality of primary health care provided in the bonus system: the level of vaccine prevention; level of breastfeeding; proactive contact with certain groups of patients; maintaining the "Risk Factors" tab in the patient's card; conducting group classes for the patient (school of patients).

It is proposed to use the technology of "key performance indicators", which list and weight are determined by interviewing the medical staff of primary care centers and are consistent with the strategic goals of primary medicine. A mathematical model of distribution of premiums among medical staff is presented, the introduction of which will allow directing the development of the primary health care system to improving its quality.

Keywords: medical staff; quality of primary health care; staff incentives; staff bonuses, key performance indicators.

Рощик И. А. ${ }^{[1 ; 0 R C I D ~ I D: ~ 0000-0002-3155-2727], ~}$
K.э.H., доцент,
Овсиюк М. В. ${ }^{[1 ; \text { ORCID ID: 0000-0001-6287-3876], }}$
соискатель высшего образования второго (магистерского) уровня

${ }^{1}$ Национальный университет водного хозяйства и природопользования, г. Ровно

\section{ПРЕМИРОВАНИЕ МЕДИЦИНСКИХ РАБОТНИКОВ В ЦЕНТРАХ ПРЕДОСТАВЛЕНИЯ ПЕРВИЧНОЙ МЕДИЦИНСКОЙ ПОМОЩИ}

На основе анализа коллективных договоров, действующих в центрах оказания первичной медицинской помощи, установлены основные характеристики системы премирования медицинских работников. Обоснована актуальность их трансформации путем переквалификации премии за заключенные декларации врачей и медицинских сестер, работающих с ними, в повышение должностного оклада и имплементации показателей качества предоставленной первичной медицинской помощи в систему премирования. Предложено применять технологию «ключевых показателей эффективности», перечень и вес которых определяются путем опроса медицинских работников центров первичной медицинской помощи и согласуются со стратегическими целями развития медицины первичного звена. Приведена математическая модель распределения премий между врачами, внедрение которой позволит реализовать стратегию развития системы первичной медицинской помощи в направлении улучшения ее качества.

Ключевые слова: медицинские работники; качество первичной медицинской помощи; стимулирование персонала; премирование персонала; ключевые показатели эффективности. 